\title{
Outbreak with a novel avian influenza $A(H 7 N 9)$ virus in China - scenarios and triggers for assessing risks and planning responses in the European Union, May 2013
}

C Schenk (cindy.schenk@ecdc.europa.eu) ${ }^{1}$, D Plachouras ${ }^{1}$, N Danielsson ${ }^{1}$, A Nicoll $^{1}$, E Robesyn ${ }^{1}$, D Coulombier $^{1}$

1. European Centre for Disease Prevention and Control (ECDC), Stockholm, Sweden

Citation style for this article:

Schenk C, Plachouras D, Danielsson N, Nicoll A, Robesyn E, Coulombier D. Outbreak with a novel avian influenza A(H7N9) virus in China - scenarios and triggers for assessing risks and planning responses in the European Union, May 2013. Euro Surveill. 2013;18(20):pii=20482. Available online: http://www.eurosurveillance. org/ViewArticle.aspx?Articleld=20

Article submitted on 30 April 2013 / published on 16 May 2013

As part of the risk assessment and strategic planning related to the emergence of avian influenza $\mathrm{A}\left(\mathrm{H}_{7} \mathrm{N9}\right)$ in China the European Centre for Disease Prevention and Control (ECDC) has considered two major scenarios. The current situation is the one of a zoonotic epidemic (Scenario A) in which the virus might be transmitted sporadically to humans in close contact with an animal reservoir. The second scenario is the movement towards efficient human to human transmission (a pandemic Scenario B). We identified epidemiological events within the different scenarios that would trigger a new risk assessment and a review of the response activities to implement in the European Union (EU). Further, we identified the surveillance activities needed to detect these events. The EU should prepare for importation of isolated human cases infected in the affected area, though this event would not change the level of public health risk. Awareness among clinicians and local public health authorities, combined with nationally available testing, will be crucial. A 'one health' surveillance strategy is needed to detect extension of the infection towards Europe. The emergence of a novel reassortant influenza $\mathrm{A}\left(\mathrm{H}_{7} \mathrm{~N} 9\right)$ underlines that pandemic preparedness remains important for Europe.

\section{Introduction}

On 31 March 2013, human cases of infection with a novel avian influenza $\mathrm{A}\left(\mathrm{H}_{7} \mathrm{~N} 9\right)$ were reported in eastern China $[1,2]$. The first two cases in Shanghai had been detected through astute clinicians alerting the public health authorities. The isolated viruses were of an un-subtypeable influenza A strain that was determined to be a novel reassortant strain by the World Health Organization (WHO) Collaborating Centre in the Chinese Center for Disease Control and Prevention in Beijing. A similar virus was identified in a third human case in Anhui province and subsequently in poultry in live bird markets in Shanghai [1,3,4]. The emergence of a novel reassortant avian influenza virus causing disease among humans is a significant threat for public health. Molecular analysis of this avian origin virus genome identified markers associated with mammalian adaptation. However, there are difficulties in interpreting the significance of molecular data from the limited number of virus sequences posted to date and without linked information on the clinical and epidemiological behaviour of the viruses in humans [2]. There is also a particular lack of data on both the geographic spread and the distribution of the viruses among avian species in China [5].

The European Centre for Disease Prevention and Control (ECDC) systematically gathers, analyses and interprets epidemic intelligence data to fulfil its mandate for risk assessment and developing guidance for Europe. For the emergence of influenza $\mathrm{A}\left(\mathrm{H}_{7} \mathrm{~N} 9\right)$ virus, we used scenario analysis as a tool for assessing risks, anticipating possible developments and prioritising preparedness activities. The aim of this paper is to identify the critical events that should inform preparedness, define surveillance priorities and be the basis for risk management options at the European level and in the European Union (EU) Member States.

\section{Scenario analysis}

The scenario analysis method was first developed after the Second World War as part of game analysis. In public health, scenario analysis is a tool for strategic planning and for preparing for future events [6]. Subsequently, the significance of a given event can be estimated based on a set of assumptions and premises $[7,8]$.

One important lesson from the influenza $A\left(\mathrm{H}_{1} \mathrm{~N}_{1}\right)$ pdmo9 pandemic in 2009 was the need for flexible planning based on a range of scenarios, which are refined as more data becomes available [9-11]. Determining the behaviour of a novel reassortant strain of an influenza virus at the early stages of its appearance is challenging. Predicting its future behaviour is impossible. The objective of the analysis in this context is to consider the most likely scenarios for how the underlying patterns of infection and transmission could evolve, and 
to identify the key events (triggers) that would prompt a re-assessment of the situation and the strategic planning.

The underlying epidemiological patterns were estimated based on the documented behaviours of avian influenza viruses, their genetic propensity to adapt to a variety of hosts and their ability to cause a broad spectrum of clinical disease in humans $[12,13]$. Some avian influenza virus subtypes cause sporadic human infections of variable severity. Efficient person-to-person transmission as a result of genetic evolution of the virus would result in a pandemic. Between these two situations, there is a theoretical phase with viruses in transition [14]. However, that phase has never been observed before a pandemic. In this theoretical transition phase, variable epidemiological patterns might be observed with different animal sources, different groups of affected humans, variable clinical severity and variety of cluster size and geographical expansion. In this situation, risk assessments have to be speculative, but can draw upon tools like the international Influenza Risk Assessment Tool (IRAT) [15,16].

Based on the above spectrum of possible human influenza infections, two scenarios were elaborated. Results from the genetic analysis of the isolated strains, the current epidemiology of the influenza $A\left(\mathrm{H}_{7} \mathrm{~N} 9\right)$ viruses in humans and the very limited knowledge of its epidemiology and behaviour in animals were taken into account [17]. Subsequently, we examined various possible developments from the current epidemiological situation (Table). We categorised the events in human versus animal health related, starting with the current situation and ordered them within each category according to significance. For this, a simple scale was used to estimate the significance of each possible development, based on the likely impact on public health in the EU as perceived by the authors. For each event we described the applicable scenario and the method to detect the event.

\section{Scenarios and triggers}

As of 16 May 2013, there are 131 laboratory-confirmed cases, including 32 deaths, with influenza $A\left(\mathrm{H}_{7} \mathrm{~N}_{9}\right)$ infection. Cases have been reported from eight provinces (Anhui, Fujian, Henan, Hunan, Jiangsu, Jiangxi, Shandong, and Zhejiang) and two municipalities (Shanghai and Beijing) in mainland China. In addition, one travel-related case is reported by Taiwan $[18,19]$.

Scenario A, the zoonotic scenario, is consistent with the current situation, as of May 2013, in which the novel influenza $\mathrm{A}\left(\mathrm{H}_{7} \mathrm{~N} 9\right)$ virus is distributed in poultry populations in an unknown area of eastern China [5]. The virus has a low pathogenicity for domestic poultry, though there is a possibility of change to high pathogenicity for poultry [5]. Whether it circulates in other animal reservoirs is yet to be determined, for example whether the virus is being transmitted from a wild bird reservoir to poultry in multiple locations or if the virus has spread to the affected areas through poultry-to-poultry transmission. The transmissibility from poultry to humans is overall low, but higher than for influenza $\mathrm{A}\left(\mathrm{H}_{5} \mathrm{~N}_{1}\right)$ and therefore resulting in occasional human infections [20]. Epidemiological and virological investigations are expected to accrue evidence over time for the exposure of cases to an animal source. Human-to-human transmissibility seems to be very low [21]. Small clusters occur, but are uncommon in this scenario where most human infections are sporadic and the clinical spectrum of disease is still unclear $[20,22]$. In some ways influenza $A\left(\mathrm{H}_{7} \mathrm{N9}\right)$ resembles the influenza $\mathrm{A}\left(\mathrm{H}_{5} \mathrm{~N}_{1}\right)$ zoonotic epidemic, but critical differences from influenza $A\left(\mathrm{H}_{5} \mathrm{~N}_{1}\right)$ include the occurrence of some mild or asymptomatic influenza $\mathrm{A}\left(\mathrm{H}_{7} \mathrm{~N} 9\right)$ cases, the absence of pathogenicity for birds at present, the somewhat higher transmissibility of influenza $\mathrm{A}\left(\mathrm{H}_{7} \mathrm{~N} 9\right)$ to human and age and sex distributions among humans which are older and more maleorientated than for influenza $\mathrm{A}\left(\mathrm{H}_{5} \mathrm{~N}_{1}\right)$. From a European perspective, travellers from the affected area might be infected and diagnosed after arriving in Europe without any change in scenario [23]. Spread of the virus to European poultry might eventually take place either through (illegal) imported birds or migratory birds and failure of biosecurity arrangements in Europe [24]. In that case, human infections might occur mainly in an occupational setting. In Europe, this is the basis for statutory surveillance for low pathogenic avian influenza viruses in poultry and wild bird surveillance [25].

Scenario B, the pandemic scenario entails the emergence of sustained human-to-human transmission resulting in a pandemic [26]. The case-fatality could be low like that of swine-origin influenza $\mathrm{A}\left(\mathrm{H}_{1} \mathrm{~N}_{1}\right)$ pdmog in 2009 or of higher magnitude akin to that of influenza $A\left(H_{1} N_{1}\right)$ in $1918[27,28]$. Should this scenario occur, the influenza $A\left(\mathrm{H}_{7} \mathrm{~N} 9\right)$ viruses were detected early in the course of adaptation and would have become increasingly transmissible between humans. An exponential increase in the number of cases and clusters as well as in cluster size would then result [29]. In this scenario, if a substantial proportion of infections were to be mild or asymptomatic, this would also facilitate the spread of the virus. Because spread would occur through humanto-human transmission rather than selective common exposure, all age groups would be exposed. Due to possible pre-existing population immunity, certain risk groups might emerge and be predominantly affected as occurred with influenza $A\left(\mathrm{H}_{1} \mathrm{~N}_{1}\right)$ pdmog [30].

Between these two scenarios, in the theoretical transition phase, multiple variants could be observed based on the dimensions of transmissibility, susceptibility and severity.

The critical events or triggers that we have identified and their likely significance or impact for Europe are listed in the Table. For each event is indicated to which scenario it could apply and which surveillance activity could detect the event. 
Critical epidemiological events (triggers) for Europe in the context of the emergence of influenza A(H7N9) in China

\begin{tabular}{|c|c|c|c|c|}
\hline \multicolumn{2}{|c|}{ Event } & $\begin{array}{l}\text { Public health significance/ } \\
\text { impact for Europe }\end{array}$ & Scenario & $\begin{array}{l}\text { How to detect event by public health } \\
\text { authorities in Europe }\end{array}$ \\
\hline \multicolumn{5}{|c|}{ Human health } \\
\hline 1. & $\begin{array}{l}\text { Clusters of }<4 \text { cases, isolated in time } \\
\text { and place }{ }^{a}\end{array}$ & $\begin{array}{l}\text { Low: no or limited human to } \\
\text { human transmission, as seen } \\
\text { with influenza } \mathrm{A}_{\left(\mathrm{H}_{5} \mathrm{~N}_{1}\right)}\end{array}$ & Zoonotic & - Epidemic intelligence ${ }^{\mathrm{b}}[38]$ \\
\hline 2. & $\begin{array}{l}\text { Locally acquired human infections } \\
\text { taking place within neighbouring } \\
\text { provinces to affected area in China }\end{array}$ & $\begin{array}{l}\text { Low: indicator of increased } \\
\text { testing or spread in bird } \\
\text { populations }\end{array}$ & Zoonotic & - Epidemic intelligence \\
\hline 3. & $\begin{array}{l}\text { Imported case in person returning } \\
\text { from affected area to Europe }\end{array}$ & $\begin{array}{l}\text { Low, but with high } \\
\text { communication impact }\end{array}$ & Zoonotic & $\begin{array}{l}\text { - Awareness among clinicians and public health } \\
\text { authorities in Europe } \\
\text { - Human surveillance (case finding algorithm, } \\
\text { laboratory capacity and case definition) }\end{array}$ \\
\hline \multirow[t]{3}{*}{4.} & \multirow{3}{*}{$\begin{array}{l}\text { Locally acquired human infections } \\
\text { in Chinese provinces not next to } \\
\text { affected area, or in neighbouring } \\
\text { countries of China }\end{array}$} & Medium, indicating either: & & \multirow[t]{3}{*}{ - Epidemic intelligence } \\
\hline & & $\begin{array}{l}\text { - increased testing or spread } \\
\text { in bird populations }\end{array}$ & Zoonotic & \\
\hline & & $\begin{array}{l}\text { - or increasing human-to- } \\
\text { human transmission }\end{array}$ & Transition & \\
\hline \multirow[t]{3}{*}{5.} & \multirow{3}{*}{$\begin{array}{l}\text { Locally acquired human infections } \\
\text { in countries distant from China } \\
\text { (excluding Europe) }\end{array}$} & High, indicating either: & & \multirow[t]{3}{*}{ - Epidemic intelligence } \\
\hline & & $\begin{array}{l}\text { - wide spread in bird } \\
\text { populations }\end{array}$ & Zoonotic & \\
\hline & & $\begin{array}{l}\text { - or increasing human-to- } \\
\text { human transmission }\end{array}$ & Transition & \\
\hline \multirow[t]{3}{*}{6.} & \multirow{3}{*}{$\begin{array}{l}\text { Locally acquired human infections in } \\
\text { Europe }\end{array}$} & High, indicating either: & & \multirow{3}{*}{$\begin{array}{l}\text { - Awareness among clinicians and public health } \\
\text { authorities in Europe } \\
\text { - Human surveillance (case finding algorithm, } \\
\text { laboratory capacity and case definition) } \\
\text { - European veterinary surveillance and link to } \\
\text { human occupational surveillance } \\
\text { - Case investigation }\end{array}$} \\
\hline & & $\begin{array}{l}\text { - spread of virus in bird } \\
\text { population in Europe }\end{array}$ & Zoonotic & \\
\hline & & $\begin{array}{l}\text { - or increasing human-to- } \\
\text { human transmission }\end{array}$ & Transition & \\
\hline 7. & $\begin{array}{l}\text { Multiple or larger clusters of human } \\
\text { infections }\end{array}$ & $\begin{array}{l}\text { High: increasing risk of } \\
\text { efficient human-to-human } \\
\text { transmission }\end{array}$ & Transition & $\begin{array}{l}\text { - Epidemic intelligence/human surveillance } \\
\text { (EU/EEA) } \\
\text { - Case investigations (EU/EEA) } \\
\text { - Cluster investigations (EU/EEA) }\end{array}$ \\
\hline 8. & $\begin{array}{l}\text { Continuous chains of human } \\
\text { transmission }\end{array}$ & $\begin{array}{l}\text { High: sustained human-to- } \\
\text { human transmission }\end{array}$ & Pandemic & $\begin{array}{l}\text { - Epidemic intelligence/human surveillance } \\
\text { (EU/EEA) } \\
\text { - Case investigations (EU/EEA) } \\
\text { - Cluster investigations (EU/EEA) }\end{array}$ \\
\hline 9. & $\begin{array}{l}\text { Apparently decreased severity/case- } \\
\text { fatality ratio }\end{array}$ & $\begin{array}{l}\text { High: compromises detection } \\
\text { of cases, resulting in } \\
\text { increased risk of spread }\end{array}$ & $\begin{array}{l}\text { Any } \\
\text { scenario }\end{array}$ & - Epidemiological evaluation \\
\hline 10. & $\begin{array}{l}\text { Primary resistance to neuraminidase } \\
\text { inhibitors }\end{array}$ & $\begin{array}{l}\text { High: compromises antiviral } \\
\text { treatment }\end{array}$ & $\begin{array}{l}\text { Any } \\
\text { scenario }\end{array}$ & $\begin{array}{l}\text { - Monitoring through EU and global (WHO) } \\
\text { reference laboratory networks }[39,40]\end{array}$ \\
\hline \multicolumn{5}{|c|}{ Animal health } \\
\hline 11. & $\begin{array}{l}\text { Isolation of virus from other animals } \\
\text { than poultry in affected areas (e.g. } \\
\text { migratory birds, swine) }\end{array}$ & $\begin{array}{l}\text { Medium: } \\
\text { change in exposure risk }\end{array}$ & Zoonotic & $\begin{array}{l}\text { - Veterinary surveillance by national } \\
\text { authorities, OIE and FAO }\end{array}$ \\
\hline 12. & $\begin{array}{l}\text { Isolation of virus from wild birds in } \\
\text { Europe }\end{array}$ & $\begin{array}{l}\text { Medium: indicating risk for } \\
\text { spread to domestic birds in } \\
\text { the EU }\end{array}$ & Zoonotic & $\begin{array}{l}\text { - Wild bird surveillance by national authorities, } \\
\text { OIE and FAO }\end{array}$ \\
\hline 13. & $\begin{array}{l}\text { Isolation of virus from domestic birds } \\
\text { in Europe }\end{array}$ & $\begin{array}{l}\text { High: indicating risk for } \\
\text { occupational exposure }\end{array}$ & Zoonotic & $\begin{array}{l}\text { - European veterinary surveillance and link to } \\
\text { human occupational surveillance }\end{array}$ \\
\hline
\end{tabular}

EEA: European Economic Area; EU: European Union; FAO: Food and Agriculture Organization of the United Nations; OIE: World Organisation for Animal Health; WHO: World Health Organization.

a Currently only the first two events have been observed in China.

b Epidemic intelligence activities, including monitoring of notifications through International Health Regulations (IHR) and Early Warning and Response System (EWRS).

c Human surveillance: severe acute respiratory illness and/or influenza-like-illness and/or seroepidemiology (consortium for the standardization of influenza seroepidemiology (CONSISE) surveys), depending on the epidemiological situation and clinical picture. 


\section{Discussion}

The emergence of a novel influenza virus infection in humans in China triggered the production of a rapid risk assessment by ECDC, which has subsequently been updated in the light of further developments. The risk of exposure may be limited to a few provinces in eastern China, but the virus may also be more widespread in poultry [5]. Recommendations for European citizens living in or visiting the affected areas have appeared in the rapid risk assessment [17]. An important consideration is that the zoonotic scenario (A) may develop slowly, not progressing towards transition scenarios. ECDC will closely monitor the epidemiological and veterinary situation and report this through updates of its risk assessment and epidemiological updates on its website. In this analysis, thirteen critical epidemiologic events within the different scenarios, summarised in a table, have been identified of which a number would have a high impact for EU. Therefore it is essential to remain alert and capable of timely detecting the occurrence of these critical events, by monitoring of the clinical spectrum of disease and the epidemiological, virological and animal health situation, internationally and in the EU. Currently only the first two events in the table, both with low significance and applicable to scenario A, have been observed in China. Two triggers with a high impact on public health in Europe (increasing resistance to treatment and an apparent decrease in severity) can appear independently of any scenario.

The final column in the table indicates particular priorities for surveillance. It stresses the importance of awareness among hospital clinicians and of surveillance among local public health authorities in Europe. Epidemic intelligence, which also serves for the detection of other threats, plays a key role in detecting events outside Europe. It shows how crucial veterinary and human surveillance is in countries outside Europe, along with transparency and adherence to the International Health Regulations and the procedures of the World Organisation for Animal Health (OIE) [31]. From the activities needed to detect the events, one can deduct the institutional partners with whom to collaborate on national and international level.

The importation into Europe of a human case is likely, given the high volume of international travel between Europe and China and the higher potential for animal to human transmission of influenza $\mathrm{A}\left(\mathrm{H}_{7} \mathrm{~N} 9\right)$ than that of influenza $A\left(\mathrm{H}_{5} \mathrm{~N}_{1}\right)$. The likelihood for importation of cases into Europe might increase if the affected area expands. However, if influenza $\mathrm{A}\left(\mathrm{H}_{7} \mathrm{~N} 9\right)$ behaves similar to influenza $A\left(\mathrm{H}_{5} \mathrm{~N}_{1}\right)$, transmission to humans is expected to decline during the summer in China and the first European imported cases may not occur in the near future. Even though the significance of the event is ranked as low, EU Member States need to be prepared to manage such cases. Some Member States have already started with this. Following consultation with Member States, ECDC has now published an interim case-finding strategy and a case definition [32].
Local accurate testing is crucial for this and together with the WHO Regional Office for Europe and the Community Network Reference Laboratory (CNRL), ECDC is facilitating the availability of accurate testing in National Influenza Centres or their equivalents in all EU and European Economic Area (EEA) countries [33]. It is important that physicians and clinical laboratories receive all relevant guidance. Also, guidance on managing contacts (prophylaxis) needs to be established and distributed prior to the event and guidance for case management and use of antivirals will be especially important given the severity of influenza $A\left(\mathrm{H}_{7} \mathrm{~N}_{9}\right)$ disease in the majority of the cases.

The probability of the appearance of influenza $\mathrm{A}\left(\mathrm{H}_{7} \mathrm{~N} 9\right)$ in wild birds in Europe is difficult to comment upon as the distribution of the virus in the wild bird population in China has not been determined [5]. In this context, it will be essential to sustain the current EU wild bird surveillance for avian influenza after validating the serological and virological tests for influenza $A\left(\mathrm{H}_{7} \mathrm{~N}_{9}\right)$ [25]. The risk of spread of infection to domestic birds in the EU is also difficult to comment upon. Importation of live birds from the Far East is prohibited, but cannot be ruled-out. A more likely scenario is that the virus spreads via the mixing of migratory birds, which might allow for westward extension of the virus. This may be a long term event, as it took influenza $A\left(\mathrm{H}_{5} \mathrm{~N}_{1}\right)$ nearly a decade to spread in wild birds from China to the EU [34]. Although some flocks of poultry were infected with influenza $\mathrm{A}\left(\mathrm{H}_{5} \mathrm{~N}_{1}\right)$, rapid detection, stringent action and high levels of biosafety stamped out the infection and the influenza $A\left(\mathrm{H}_{5} \mathrm{~N}_{1}\right)$ has never become established in EU poultry the way it has in domestic birds in countries with more informal poultry sectors [25]. An important distinction is that influenza $\mathrm{A}\left(\mathrm{H}_{7} \mathrm{~N} 9\right)$ is currently a low pathogenic avian influenza virus for birds and will not produce the characteristic 'die-offs' signal which trigger testing of poultry flocks. Hence, the statutory low pathogenicity surveillance will become more important for human health. The mandate of public health agencies will not cover animal surveillance and the current collaboration with animal health agencies will need to be intensified under the one health surveillance strategy with greater emphasis on occupational surveillance. In the event of influenza $\mathrm{A}\left(\mathrm{H}_{7} \mathrm{~N} 9\right)$ being detected in domestic animals in the EU, it will be especially important for national public health and animal health authorities to collaborate intensively to ensure timely exchange of surveillance data and early recognition of potential human cases. Occupational guidance to prevent human infections from poultry should build on that for influenza $\mathrm{A}\left(\mathrm{H}_{5} \mathrm{~N}_{1}\right)$.

Though the risk of person-to-person transmission of influenza $A\left(\mathrm{H}_{7} \mathrm{~N} 9\right)$ resulting in disease seems to be low at present, the infection of a human with influenza $\mathrm{A}\left(\mathrm{H}_{7} \mathrm{~N} 9\right)$ by transmission within Europe will be a critical event with high significance. Agreed guidance for the assessment of human-to-human transmission will be necessary using the consortium for the standardization 
of influenza seroepidemiology (CONSISE) protocols and their national counterparts established for other respiratory infections [35,36]. In addition, epidemiological studies need to be prepared and agreed between countries to identify risk factors among hospitalised cases in the EU. This should again build on routine severe disease surveillance and the CONSISE protocols [37]. The appearance of expanding clusters or chains of transmission, and eventually sustained human-tohuman transmission would be another highly significant critical event. Finally, the appearance of influenza $A\left(\mathrm{H}_{7} \mathrm{~N} 9\right)$ indicates that revising pandemic plans and preparedness in light of the 2009 experience and the anticipated new guidance from WHO should remain a priority for Europe.

In Scenario A, a zoonotic epidemic, the production of a manufactured human vaccine is not of highest priority, though candidate viruses and reagents are being developed by the WHO guided strain selection system as they were previously for other zoonotic viruses of pandemic potential, $A\left(\mathrm{H}_{7}\right)$ and $\mathrm{A}\left(\mathrm{H}_{9}\right)$ viruses. Decisions on whether to progress to the development of clinical lots to allow early clinical trials, for example for determining dosage and efficacy, will be a matter of judgment informed by tools like the IRAT $[15,16]$. Relevant CONSISE studies will again be essential in order to determine background protection in the European population [35,36].

\section{Conclusions}

The confirmation of novel avian influenza virus infections in humans is a significant threat for public health because of the potential for the virus to develop into a pandemic strain [26] and demonstrates the importance of pandemic preparedness. Developing and examining possible outbreak scenarios and identifying critical events are essential exercises to assess risks. The currently most probable scenario is one of sporadic human infections caused by exposure to birds but with a yet undetermined animal reservoir. Neither importation of human cases into the EU nor limited person-to-person transmission in the currently affected areas [29] would be of significance or change the scenario. Events of medium significance include increasing geographical spread of human infections within China and neighbouring countries, isolation of viruses in animals other than domestic birds or detection of virus in wild birds in Europe. Highly significant events include: transmission in countries distant from China, isolation of viruses from domestic birds in Europe, locally acquired infections in Europe and sustained human-to-human transmission. Epidemic intelligence is crucial for detecting trigger events. Public health authorities and clinicians need to be aware of surveillance guidance and laboratory testing needs to be made available. A comprehensive human and veterinary surveillance strategy is needed to detect extension of the infection towards Europe.
Authors' contributions

All authors were involved in the development of the scenarios and identification of the critical events. Cindy Schenk, Diamantis Plachouras, Niklas Danielsson, Emmanuel Robesyn drafted the manuscript, which was critically reviewed by Angus Nicoll and Denis Coulombier.

\section{Conflict of interest}

None declared.

\section{References}

1. Nicoll A, Danielsson N. A novel reassortant avian influenza $A\left(\mathrm{H}_{7} \mathrm{~N} 9\right)$ virus in China - what are the implications for Europe. Euro Surveill. 2013;18(15):pii=20452. Available from: http:/ www.eurosurveillance.org/ViewArticle.aspx?Articleld $=20452$

2. Gao R, Cao B, Hu Y, Feng Z, Wang D, Hu W, et al. Human Infection with a Novel Avian-Origin Influenza A $\left(\mathrm{H}_{7} \mathrm{Ng}\right)$ Virus. N Engl J Med. 2013 Apr 11. http://dx.doi.org/10.1056/ NEJMoa1304459

3. World Organisation for Animal Health (OIE). Low pathogenic avian influenza (poultry), China (People's Rep. of). Paris: OIE; 2013. Updated 26 April 2013. [Accessed 6 May 2013]. Available from: http://www.oie.int/wahis_2/public/wahid.php/ Reviewreport/Review?page_refer=MapFullEventReport\&repor tid $=13225$

4. Centers for Disease Control and Prevention (CDC). Emergence of Avian Influenza $\mathrm{A}\left(\mathrm{H}_{7} \mathrm{~N} 9\right)$ Virus Causing Severe Human Illness - China, February-April 2013. MMWR Morb Mortal Wkly Rep. 2013 May 10;62(18):366-71. PMid:23657113

5. Zhuang QY, Wang SC, Wu ML, Liu S, Jiang WM, Hou GY, et al. Epidemiological and risk analysis of the $\mathrm{H}_{7} \mathrm{~N} 9$ subtype influenza outbreak in China at its early stage. Chin. Sci. Bull. 2013. Available from: http://link.springer.com/content/ pdf/10.1007\%2Fs11434-013-5880-5.pdf

6. Venable JM, Ma QL, Ginter PM, Duncan WJ. The use of scenario analysis in local public health departments: alternative futures for strategic planning. Public Health Rep. 1993;108(6):701-10. PMid:8265754 PMCid:1403452

7. van Genugten ML, Heijnen ML, Jager JC. Pandemic influenza and healthcare demand in the Netherlands: scenario analysis. Emerg Infect Dis. 2003;9(5):531-8. http://dx.doi.org/10.3201/ eido905.020321 PMCid:2972752

8. Snacken R, Kendal AP, Haaheim LR, Wood JM. The next influenza pandemic: lessons from Hong Kong, 1997. Emerg Infect Dis. 1999;5(2):195-203. http://dx.doi.org/10.3201/ eid0502.990202 PMid:10221870 PMCid:2640700

9. Nicoll A, Sprenger M. Learning lessons from the 2009 pandemic: putting infections in their proper place. Eur J Epidemiol. 2011;26(3):191-4. http://dx.doi.org/10.1007/s10654011-9575-4 PMid:21487957 PMCid:3079088

10. European Centre for Disease prevention and Control (ECDC). Avian influenza: Guidance for National Authorities to Produce Messages for the Public Concerning the Protection of Vulnerable Groups. Stockholm: ECDC; Feb 2006. Available from: http://ecdc.europa.eu/en/publications/ Publications/0602_TER_Avian_Influenza_Guidance_for_ National_Authorities.pdf

11. World Health Organisation (WHO). Report of the Review Committee on the Functioning of the International Health Regulations (2005) in relation to Pandemic (H1N1) 2009. Geneva: WHO; 5 May 2011. Available from: http://apps.who. int/gb/ebwha/pdf_files/WHA64/A64_10-en.pdf

12. Watanabe $Y$, Ibrahim MS, Suzuki Y, Ikuta K. The changing nature of avian influenza A virus $\left(\mathrm{H}_{5} \mathrm{~N}_{1}\right)$. Trends Microbiol. 2012;20(1):11-20. http://dx.doi.org/10.1016/j.tim.2011.10.003 PMid:22153752

13. Writing Committee of the Second World Health Organization Consultation on Clinical Aspects of Human Infection with Avian Influenza $\mathrm{A}\left(\mathrm{H}_{5} \mathrm{~N}_{1}\right)$ virus, Abdel-Ghafar AN, Chotpitayasunondh T, Gao Z, Hayden FG, Nguyen DH, et al. Update on avian influenza $A\left(\mathrm{H}_{5} \mathrm{~N}_{1}\right)$ virus infection in humans. $N$ Engl J Med. 2008;358(3):261-73. http://dx.doi.org/10.1056/NEJMra0707279 PMid:18199865

14. Ferguson NM, Cummings DA, Cauchemez S, Fraser C, Riley S, Meeyai A, et al. Strategies for containing an emerging influenza pandemic in Southeast Asia. Nature. 2005;437(7056):209-14. http://dx.doi.org/10.1038/ nature04017 PMid:16079797 
15. Trock SC, Burke SA, Cox NJ. Development of an influenza virologic risk assessment tool. Avian Dis. 2012;56(4 Suppl):1058-61. http://dx.doi.org/10.1637/10204-041412ResNote.1 PMid:23402136

16. Centers for Disease Control and Prevention (CDC). Influenza Risk Assessment Tool (IRAT) CDC: Atlanta; 21 Jun 2012. [Accessed 28 Apr 2013]. Available from: http://www.cdc.gov/ flu/pandemic-resources/tools/risk-assessment.htm

17. European Centre for Disease prevention and Control (ECDC). Updated Rapid Risk Assessment. Human infection with a novel avail influenza virus, $\mathrm{A}\left(\mathrm{H}_{7} \mathrm{Ng}\right)$ - China. Stockholm: ECDC;.8 May 2013. Available from: http://ecdc.europa.eu/en/ publications/Publications/influenza- $\mathrm{A}\left(\mathrm{H}_{7} \mathrm{~N}\right.$ 9)-China-rapid-riskassessment-8-may-2013.pdf

18. Lo YC, Chen WC, Huang WT, Lin YC, Liu MC, Kuo HW,et al. Surveillance of avian influenza $\mathrm{A}\left(\mathrm{H}_{7} \mathrm{~N} 9\right)$ virus infection in humans and detection of the first imported human case in Taiwan, 3 April to 10 May 2013. Euro Surveill. 2013. 18(20): $\mathrm{pii}=20479$. Available from: http://www. eurosurveillance.org/ViewArticle.aspx?Articleld =20479

19. Chang SY, Lin PH, Tsai JC, Hung CC, Chang SC. The first case of $\mathrm{H}_{7} \mathrm{~N} 9$ influenza in Taiwan. Lancet. 2013;381(9878): 1621. http://dx.doi.org/10.1016/S0140-6736(13)60943-5

20. Li Q, Zhou L, Zhou M, Chen Z, Li F, Wu H, et al. Preliminary Report: Epidemiology of the Avian Influenza A ( $\left.\mathrm{H}_{7} \mathrm{~N} 9\right)$ Outbreak in China. N Engl J Med. 2013 Apr 24. http://dx.doi.org/10.1056/ NEJMoa1304617

21. World Health Organisation (WHO). WHO Risk Assessment, Human infections with avian influenza $A\left(\mathrm{H}_{7} \mathrm{~N} 9\right)$ virus. Geneva: WHO; 10 May 2013. [Accessed 16 May 2013]. Available from: http://www.who.int/influenza/human animal interface/ influenza h7n9/RiskAssessment_H7N9_10May13.pdf

22. Van Kerkhove MD, Riley S, Lipsitch M, Guan Y, Monto AS, Webster RG, et al. Comment on "Seroevidence for $\mathrm{H}_{5} \mathrm{~N}_{1}$ influenza infections in humans: meta-analysis". Science. 2012;336(6088):1506; author reply 1506. http://dx.doi. org/10.1126/science.1221434 PMid:22723396

23. Centers for Disease Control Taiwan. The first imported human infection with avian influenza A(H7N9) confirmed in Taiwan 2013. Taiwan: Centers for Disease Control Taiwan; 24 Apr 2013. [Accessed 28 Apr 2013]. Available from: http://www.cdc.gov. tw/english/info.aspx?treeid=EEoA2987CFBA3222\&nowtreeid= D3C5BBCF8E6oCF3D\&tid=DCD2943FEE3FCB75

24. Suetens C, Snacken R, Hanquet G, Brochier B, Maes S, Thomas I, et al. Eagles testing positive for $\mathrm{H}_{5} \mathrm{~N}_{1}$ imported illegally into Europe from Thailand. Euro Surveill. 2004;8(44) pii=2575. Available from: http://www.eurosurveillance.org/ViewArticle. aspx?Articleld $=2575$

25. European Commission DHaC. Surveillance for Avian Influenza. [Accessed29 Apr 2013]. Available from: http:// ec.europa.eu/food/animal/diseases/controlmeasures/avian/ eu resp_surveillance_en.htm

26. Kilbourne ED. Influenza pandemics of the 2oth century. Emerg Infect Dis. 2006;12(1):9-14. http://dx.doi.org/10.3201/ eid1201.051254 PMid:16494710 PMCid:3291411

27. Reed C, Biggerstaff M, Finelli L, Koonin LM, Beauvais D, Uzicanin A, et al. Novel framework for assessing epidemiologic effects of influenza epidemics and pandemics. Emerg Infect Dis. 2013;19(1):85-91. http://dx.doi.org/10.3201/ eid1901.120124 PMid:23260039 PMCid:3557974

28. Dawood FS, Iuliano AD, Reed C, Meltzer MI, Shay DK, Cheng PY, et al. Estimated global mortality associated with the first 12 months of 2009 pandemic influenza $\mathrm{A} \mathrm{H}_{1} \mathrm{~N}_{1}$ virus circulation: a modelling study. Lancet Infect Dis. 2012;12(9):687-95. http:// dx.doi.org/10.1016/S1473-3099(12)70121-4

29. Nicoll $A$. (Yet) another human $A / \mathrm{H}_{5} \mathrm{~N}_{1}$ influenza case and cluster - when should Europe be concerned? Euro Surveill. 2008;13(15): pii=18833. Available from: http://www. eurosurveillance.org/ViewArticle.aspx?Articleld=18833

30. Amato-Gauci A, Zucs P, Snacken R, Ciancio B, Lopez V, Broberg $E$, et al. Surveillance trends of the 2009 influenza $A\left(\mathrm{H}_{1} \mathrm{~N}_{1}\right)$ pandemic in Europe. Euro Surveill. 2011;16(26);pii=19903. Available from: http://www.eurosurveillance.org/ViewArticle. aspx?Articleld=19903 PMid:21745444

31. Heymann D, Mackenzie JS, Peiris M. SARS legacy: outbreak reporting is expected and respected. Lancet. 2013;381(9869):779-81. http://dx.doi.org/10.1016/ So140-6736(13)60185-3

32. European Centre for Disease prevention and Control (ECDC). Proposed interim case definition and case finding algorithm for reporting patients infected by the avian influenza $A\left(\mathrm{H}_{7} \mathrm{~N} 9\right)$ virus in EU/EEA Member States 2013. Stockholm: ECDC; 3 May 2013. [Accessed 6 May 2013]. Available from: http:// ecdc.europa.eu/en/publications/Publications/Forms/ECDC DispForm.aspx?ID=1114
33. CNRL/ECDC/WHO Europe. Diagnostic preparedness in Europe for detection of avian influenza $\mathrm{A}\left(\mathrm{H}_{7} \mathrm{~N} 9\right)$ viruses. Stockholm: European Centre for Disease Control and Prevention; 24 Apr 2013/ [Accessed 2 May 2013]. Available from: http:// ecdc.europa.eu/en/publications/Publications/Forms/ECDC_ DispForm.aspx?ID=1103

34. World Health Organisation (WHO). $\mathrm{H}_{5} \mathrm{~N}_{1}$ avian influenza: Timeline of major events. Geneva: WHO; 13 Dec 2011. Available from: http://www.who.int/influenza/human_animal_interface/ avian_influenza/H5N1_avian_influenza_update.pdf

35. Van Kerkhove MD, Broberg E, Engelhardt OG, Wood J, Nicoll A; CONSISE steering committee. The consortium for the standardization of influenza seroepidemiology (CONSISE): a global partnership to standardize influenza seroepidemiology and develop influenza investigation protocols to inform public health policy. Influenza Other Respi Viruses. 2013;7(3):231-4. http://dx.doi.org/10.1111/irv.12068 PMid:23280042

36. European Centre for Disease prevention and Control (ECDC). Ferrets as experimental models of influenza in humans 2013. Stockholm: ECDC; 7 Mar 2013. [Accessed 6 May ]. Available from: http://ecdc.europa.eu/en/activities/sciadvice/Lists/ ECDC\%2oReviews/ECDC_DispForm.aspx?List $=512 \mathrm{ff}_{74} \mathrm{f} \% 2 \mathrm{D} 7$ $7 \mathrm{~d} 4 \% 2 \mathrm{D} 4 \mathrm{ad} 8 \% 2 \mathrm{Db} 6 \mathrm{~d} 6 \% 2 \mathrm{Dbfof} 23083 \mathrm{f} 30$ \&ID $=1260$ \& RootFol der $=\% 2$ Fen $\% 2$ Factivities $\% 2$ Fsciadvice $\% 2$ FLists $\% 2$ FECDC $\% 20$ Reviews

37. Beaute J, Broberg E, Plata F, Bonmarin I, O Donnell J, Delgado $C$, et al. Overrepresentation of influenza $A\left(\mathrm{H}_{1} \mathrm{~N}_{1}\right)$ pdmog virus among severe influenza cases in the $2011 / 12$ season in four European countries. Euro Surveill. 2012;17(9): $\mathrm{pii}=20105$. Available from: http://www.eurosurveillance.org/ViewArticle. aspx?Articleld $=20105$

38. Kaiser R, Coulombier D, Baldari M, Morgan D, Paquet C. What is epidemic intelligence, and how is it being improved in Europe? Euro Surveill. 2006;11(5):pii=2892. Available from: http://www.eurosurveillance.org/ViewArticle. aspx?Articleld $=2892$

39. World Health Organisation (WHO). Global Influenza Surveillance and Response System (GISRS). Geneva: WHO; [Accessed 7 May 2013]. Available from: http://www.who.int/ influenza/gisrs_laboratory/en/

40. European Centre for Disease prevention and Control (ECDC). Influenza virus characterisation, summary Europe - Surveillance reports published by ECDC and Community Network of Reference Laboratories (CNRL) for Human Influenza in Europe. Stockholm: ECDC; 11 Apr 2013. [Accessed 7 May 2013]. Available from: http://ecdc.europa.eu/en/healthtopics/ seasonal influenza/epidemiological data/Pages/Influenza virus characterisation.aspx 